\title{
İlkokul Öğrencilerine Yönelik Kültürel Mirasa Duyarlılık Ölçeği’nin Geçerlik ve Güvenirlik Çalışması*
}

\author{
Hicran Hanım Halaç** , Ömür Gürdoğan Bayır****, \\ Tuba Çengelci Köse ${ }^{* * * * *}$
}

Geliş Tarihi: $15 / 10 / 2020$

Makale Kabul Tarihi: 04/12/2020

DOI:10.35675/befdergi.810944

$\ddot{O} z$

Bu araştırmanın amacı ilkokul öğrencilerinin kültürel mirasa duyarlılık düzeyini belirlemeye yönelik geçerli ve güvenilir bir ölçme aracı geliştirmektir. Kültürel mirasa duyarlılık ölçeğinin üç alt faktörü toplam varyansın \%47.335'ini açıklamaktadır. Ölçeğin KMO değeri, .85 olup, Bartlett Küresellik Testi sonucunun .01 düzeyinde anlamlı olduğu görülmektedir $\left(X^{2}=1090.218 . s d=78 . p<.001\right)$. Ölçeğin güvenirlik analizleri sonucunda tamamına ilişkin alpha katsayısı .79'tur. Yapılan geçerlik ve güvenirlik analizleri kapsamında üç boyutlu dörtlü likert tipi bir ölçme aracı geliştirilmiştir. Elde edilen Kültürel Mirasa Duyarlılık Ölçeği "Merak Duyma", "Geleceğe Aktarma” ve "Koruma” alt boyutlarından oluşmaktadır. Ölçekten alınabilecek en yüksek puan 52 iken, en düşük puan 13 'dür. Ölçekten alınan puan yükseldikçe kültürel mirasa duyarlılık yükselmektedir. Ayrıca Kültürel Mirasa Duyarlılık Ölçeği'nin açımlayıcı faktör analizi sonucunda ortaya konulan yapısının doğrulayıcı faktör analizi ile doğrulandı̆̆ı sonucuna ulaşılmıştır.

Anahtar Kelimeler: Açımlayıcı faktör analizi, doğrulayıcı faktör analizi, kültürel mirasa duyarlılık, ölçek

\section{Reliability and Validity Work of Cultural Heritage Sensitivity Scale For Primary Education Students}

\section{Abstract}

In this study, it is aimed to develop a valid and reliable measurement tool to measure cultural heritage sensitivity of primary school students. Three sub-factors of the scale of

\footnotetext{
* Bu çalışma 1005-Tarihsel Oyun Yolculuğu (TOY) başlıklı 217K009 no'lu TÜBİTAK projesinden üretilmiştir. .

** Eskişehir Teknik Üniversitesi, Mimarlık ve Tasarım Fakültesi, Mimarlık Bölümü, Restorasyon Anabilim Dalı, Eskişehir, Türkiye, hhhalac@eskisehir.edu.tr, ORCID: 00000001-8046-9914

*** Anadolu Üniversitesi, Eğitim Fakültesi, Temel Eğitim Bölümü, Sınıf Eğitimi Anabilim Dalı, Eskişehir, Türkiye, ogurdogan @ anadolu.edu.tr, ORCID: 0000-0002-7455-7237

**** Anadolu Üniversitesi, Eğitim Fakültesi, Türkçe ve Sosyal Bilimler Eğitimi Bölümü, Sosyal Bilgiler Eğitimi Anabilim Dalı, Eskişehir, Türkiye, tubacengelci@anadolu.edu.tr, ORCID: 0000-0002-9193-4313
}

Kaynak Gösterme: Halaç, H. H., Gürdoğan Bayır, Ö., \& Çengelci Köse, T. (2021). İlkokul öğrencilerine yönelik kültürel mirasa duyarlılık ölçeği'nin geçerlik ve güvenirlik çalışması. Bayburt Eğitim Fakültesi Dergisi, 16(31), 197-218. https://doi.org/10.35675/befdergi.810944. 
sensitivity to cultural heritage explain $47.335 \%$ of the total variance. The KMO value of the scale is .85, and Bartlett's Test of Sphericity is found to be significant at the level of .01 [Chi Square $=1090.218 . s d=78 . p<.001)$. As a result of the reliability analysis of the scale, the alpha coefficient for the whole is.79. Within the scope of validity and reliability analyzes, a three-dimensional four-dimensional Likert type measurement tool was developed. The Scale of Sensitivity to Cultural Heritage consists of "Curiosity", "Transferring to the Future" and "Protection" sub-dimensions. The higher the score on the scale points out the higher the sensitivity to cultural heritage. In addition, it was concluded that the structure of the Cultural Heritage Sensitivity Scale resulting from exploratory factor analysis was confirmed by confirmatory factor analysis.

Keywords: Confirmatory factor analysis, cultural heritage sensitivity, exploratory factor analysis, scale

\section{Giriş}

Kültür, bir toplumun yaşam birikimini oluşturur. Öğrenilebilir olma özelliği ile kuşaktan kuşağa aktarılan kültür, tarihî ve süreklidir. Topluma özgü olmasının yanı sıra ideal ya da idealleştirilmiş kurallar sistemini içerir, değişim ve bütünleştiricilik özelliklerine sahiptir (Güvenç, 2002, ss.101-104). Kültür sözcügü farklı düşünce sistemlerinde ve entelektüel disiplinlerde önemli kavramlar için kullanılmaktadır. Tarih, sosyoloji, antropoloji ve psikoloji gibi disiplinler sözü edilen alan içinde yer almaktadır. Kültürün tarihsel ve sosyal boyutu ise belli bir disiplin alanı içinde kalmasından ziyade öğrenilebilirliği ve sürekliliğinden kaynaklanmaktadır (Oğuz, 2011, s.137).

Kültürün aktarılabilir olması ve sürekliliği, kültürel miras kavramını ön plana çıkarır. Miras daha çok tarihle ilişkilendirilen bir kavram olmasına karşın kültürel miras bugün odaklı bir yapı gösterir. Tarihsel olaylarla ilgili ortak hafıza ile mirasın değerlerle vurgu yapan yönü bugünün gereksinimlerine de yanıt verir (Darian Smith Pascoe, 2013, s.3). Kültürel miras, daha önceki kuşaklar tarafından oluşturulmuş ve evrensel değerlere sahip olduğu kabul edilen eserler için kullanılan genel bir kavramdır (Halaç \& Demir, 2017). Önceleri kültürel miras tanımlamasında tarihi ve sanatsal değer yeterli görülürken daha sonra kültürel miras; kültürel değer, kimlik değeri ve ortak hafıza ile etkileşim kapasitesi taşıyan eserler için kullanılan bir yapıya dönüşmüştür (Vecco, 2010, s.324). Kültürel miras tanımı, kültürün hangi öğelerinin geleceğe taşınacak değerde bir miras özelliği gösterdiğinin karar verilmesine ilişkin aktif bir seçimi gerektirir (Blake, 2000).

UNESCO tarafindan yapılan sınıflamada kültürel miras somut ve somut olmayan kültürel miras biçiminde iki başlık altında incelenmektedir (UNESCO, 1972; UNESCO, 2003). Somut kültürel miras alanlarını tanımlama bağlamında, UNESCO'nun 17 Ekim-21 Kasım 1972 tarihleri arasında Paris'te yapılan XVII. dönem toplantısında müzakere edilen "Dünya Kültürel ve Doğal Varlığının 
Korunmasına Dair Sözleşme"nin birinci ve ikinci maddesinde aşağıdaki mirasların kültürel ve doğal miraslar olarak sayılacağı belirtilmiştir (UNESCO, 1972):

"Anıtlar: Tarih, sanat veya bilim açısından istisnaî evrensel değerdeki mimari eserler, heykel ve resim alanındaki şaheserler, arkeolojik nitelikte eleman veya yapılar, kitabeler, mağaralar ve eleman birleşimleri.

Yapı toplulukları: Mimarileri, uyumlulukları veya arazi üzerindeki yerleri nedeniyle tarih, sanat veya bilim açısından istisnaî evrensel değere sahip ayrı veya birleşik yapı toplulukları.

Sitler: Tarihsel, estetik, etnolojik veya antropolojik bakımlardan istisnaî evrensel değeri olan insan ürünü eserler veya doğa ve insanın ortak eserleri ve arkeolojik sitleri kapsayan alanlar.

Estetik veya bilimsel açıdan istisnaî evrensel değeri olan, fiziksel ve biyolojik oluşumlardan veya bu tür oluşum topluluklarından müteşekkil doğal anitlar.

Bilim veya muhafaza açısından istisnaî evrensel değeri olan jeolojik ve fizyografik oluşumlar ve tükenme tehdidi altındaki hayvan ve bitki türlerinin yetiştiği kesinlikle belirlenmiş alanlar.

Bilim, muhafaza veya doğal güzellik açısından istisnaî evrensel değeri olan doğal sitler veya kesinlikle belirlenmiş doğal alanlar."

Somut kültürel mirasın tanımlanması konusunda yapılan bu ayrımın belirleyici ve işlevsel olduğu görülmektedir. UNESCO, somut kültürel mirasın yanı sıra somut olmayan kültürel mirasın da korunması ve geleceğe aktarılması konusunda çalışmalar yapmaktadır. Somut olmayan kültür varlıklarının korunması konusunda önemli kilometre taşlarından biri UNESCO'nun 32. Genel Konferansında 17 Ekim 2003 tarihinde kabul edilen Somut Olmayan Kültürel Mirasın Korunması Sözleşmesi'dir (Oğuz, 2008). Bu sözleşme, Türkiye'de 19.01.2006 tarihinde TBMM'de görüşülüp kabul edilmiştir. 21 Ocak 2006 tarih ve 26056 Sayılı Resmi Gazete'de yayımlanarak yürürlüğe girmiştir. Sözleşmede somut olmayan kültürel mirasın aşağıdaki alanları kapsadığ 1 belirtilmektedir (UNESCO, 2003):

a. Somut olmayan kültürel mirasın anlatılmasında dilin bir araç olarak kullanıldığı dile dayalı söylemler ve dile dayalı gelenekler

b. Gösteri sanatları

c. Halkın ortak etkinlikleri, ritüeller ve festivaller

d. Halk Bilgisi, evren ve doğa ile ilgili uygulamalar

e. El sanatları değerleri 
Sözleşmede koruma teriminin somut olmayan kültürel mirasın yaşayabilirliğini güvence altına alma anlamına geldiği vurgulanmaktadır. Koruma kapsamına belgeleme, araştırma, muhafaza, koruma, geliştirme, güçlendirme, okul içi ya da okul dışı eğitim aracılığıyla kuşaktan kuşağa aktarma ile kültürel mirasın değişik yanlarının canlandırılmasının dahil olduğu belirtilmektedir (teftis.ktb.gov.tr, 2003). Kültürel miras eğitiminde somut kültürel mirasla birlikte somut olmayan kültürel mirasın da öğretilmesi, somut olmayan kültürel mirasa değer verilmesi ve somut olmayan kültürel mirasın korunarak gelecek nesillere aktarılması gerekmektedir. Kültürün korunup gelecek nesillere aktarılmasında duyarlılık değeri önem taşımaktadır.

Duyarlılık "yaşadığımız dünyayla ve olaylarla ilişki kurmak ve bu konuda sorumluluk almak” biçiminde tanımlanmaktadır (Keskin \& Öğretici, 2013, s.151). Kültüre duyarlılık "kültürel farklılıklara açık olma ve saygı duyma, diğer kültürün dinamiklerini anlama” (McMurray 2003'ten aktaran Ruddock \& Turner, 2007, s.362) şeklinde ifade edilmektedir. Bu bağlamda kültürel mirasa duyarlılık, kültürü oluşturan somut ve somut olmayan unsurları tanıma ve anlamaya çalışma, değer verme ve koruma için sorumluluk alma biçiminde tanımlanabilir. Kültürel mirasa duyarlılığın bir değer olarak bireylerde geliştirilmesi kültürün korunarak geleceğe taşınmasında önemli bir rol oynamaktadır.

Kültürel mirasın korunarak yaşatılması ve geleceğe aktarılması, ulusal ve uluslararası yasalar, tüzükler ve sözleşmeler bağlamında çağdaş toplumların temel sorumluluklarından biri durumundadır. Koruma ve yaşatmaya verilen önem ve bu konudaki başarı çağdaşlaşmanın temel göstergelerinden biri olarak değerlendirilmektedir. Sürdürülebilir koruma ve yaşatma, kültürel mirasa ilişkin farkındalık oluşturmaya ve toplumun bu konudaki bilinçlenmesi ve katılımına bağlıdır (Halaç, Mokrane \& Turan, 2019). Toplumun somut ve somut olmayan kültürel mirasının korunarak gelecek kuşaklara aktarılması noktasında kültürel miras eğitimi çalışmalarının gerekliliği ortaya çıkar. Çocuk ilk olarak ailesinde ve yakın çevresinde kültüre ilişkin bilgi ve deneyimini kazanır. Kuşkusuz çocuğun kültürel mirasa ilişkin alg1 ve deneyiminin oluşmasında da ailenin büyük etkisi vardır. Daha sonra eğitim kurumlarında kültür ve kültürel mirasa yönelik kazanımlar gerçekleştirilmeye çalışılır. İlköğretim öğrencilerde kültüre ve kültürel mirasa yönelik farkındalığın yaratılmasında ve kültürel miras eğitimi verilmesinde önemli bir eğitim basamağıdır. Kültürel miras eğitiminde tarihin ve kültürün temel kavramlarının ve ilkelerinin öğretilmesi amaçlanır (Çulha Özbaş, 2009). Kültürel miras eğitimi ilkokulda özellikle Hayat Bilgisi ve Sosyal Bilgiler gibi öğrencilere ailesini ve içinde yaşadığ 1 toplumu sosyal ve kültürel yönleriyle tanıtmayı amaçlayan derslerde ön plana çıkmaktadır. Sosyal Bilgiler dersinde yer alan Kültür ve Miras öğrenme alanı doğrudan doğruya "Türk kültürünü oluşturan temel ögelerden hareketle kültürün korunması ve geliştirilmesini sağlayacak bir millî bilincin oluşturulmasını amaçlamaktadır” (Milli Eğitim Bakanlığı [MEB, 2018], s.11). 4. sınıf düzeyinde Kültür ve Miras alanıyla ilgili kazanımlara örnek olarak "Ailesi ve çevresindeki millî kültürü yansitan ögeleri araştırarak örnekler verir.” (MEB, 2018, s.15) kazanımı dikkat çekicidir. 
Ailede ve örgün eğitim kurumlarında verilen eğitimle öğrencilerin kültürel miras konusunda duyarlılık kazanmaları, bu mirasın aktarılmasında sorumluluk hissetmelerine temel oluşturur. Bu nedenle eğitim programlarında kültürel mirasa yönelik kazanımlara yer verilmesi ve bu kazanımların etkili biçimde uygulama aktarılması gerekir (Avc1 \& Memişoğlu, 2016; Çengelci, 2012). Somut kültürel mirasın korunması kapsamında öğrencilerin aktif olacağı etkinlikler ve gezilerden yararlanılabilir. Somut kültürel miras ile ilgili gezilerde oyun gibi etkinlikler öğrencilerin eğlenceli zaman geçirmesini sağladığından kültürel miras öğelerine daha fazla ilgi göstermelerine yardımcı olmaktadır (Dönmez \& Yeşilbursa, 2014). Kültürel miras eğitiminde planlı ve öğrencilere deneyim sağlayan uygulamalar öğrencilerde kültürel mirasa yönelik farkındalık oluşturmada etkili olacaktır (Gürdoğan Bayır \& Çengelci Köse, 2019). Bu nedenle farklı eğitim uygulamalarının öğrencilerin kültürel mirasa yönelik duyarlılığına etkisini belirlemede öğrencilerin kültürel mirasa duyarlılığını değerlendirecek bir ölçme aracının geliştirilmesi önem taşımaktadır. Alanyazında kültürlerarası duyarlılık ölçeği (Chen \& Starosta, 2000); kültürel miras tutum ölçeği (Curtis \& Seymour, 2004), somut kültürel miras tutum ölçeği (Yeşilbursa, 2011), somut olmayan kültürel miras tutum ölçeği (Gürel \& Çetin, 2019) gibi ölçekler bulunmaktadır. Ancak alanyazında öğrencilerin kültürel mirasa duyarlılıklarını belirlemeyi amaçlayan bir ölçme aracına rastlanmamıştır. $\mathrm{Bu}$ araştırma da sözü edilen gereksinimden kaynaklanmaktadır.

\section{Araştırmanın Amacı}

$\mathrm{Bu}$ araştırmanın amacı ilkokul öğrencilerinin kültürel mirasa duyarlılıklarını belirleyebilecek geçerli ve güvenilir bir ölçme aracının geliştirilmesidir.

\section{Yöntem}

$\mathrm{Bu}$ araştırma ilkokul öğrencilerinin kültürel mirasa duyarlılıklarını belirlemek için oluşturulmuş bir ölçek geliştirme araştırmasıdır.

Araştırma için gerekli etik kurul onayı, Anadolu Üniversitesi Sosyal ve Beşerî Bilimler Bilimsel Araştırma ve Yayın Etiği Kurulu yazısı ile alınmıştır.

\section{Çalışma Grubu}

Araştırmanın verileri 2019-2020 güz döneminde öğrenim gören ilkokul 3. ve 4. sinıf öğrencilerinden toplanmıştır. Araştırmada açımlayıcı ve doğrulayıcı faktör için ayrı ayrı örneklem gruplarından yararlanılmıştır. Örneklemin belirlenmesinde katılımcıların kimi özellikleri dikkate alınarak evreni temsil etmesini sağlayan tabakalı örneklem (Ekiz, 2009) kullanılmıştır. Bu kapsamda öncelikle Eskişehir ili Tepebaşı ilçesindeki ilkokullar sosyoekonomik düzeyleri göz önünde bulundurularak tabakalara ayrılmış, bu tabakalardaki okullardan basit yansız örneklem alınmıştır. $\mathrm{Bu}$ bağlamda araştırmada açımlayıcı faktör analizine 539, doğrulayıcı faktör analizine ise 
327 öğrenci katılmıştır. Araştırmaya katılan öğrencilerin kişisel özellikleri Tablo 1'de sunulmuştur.

Tablo 1.

Ölçek Geliştirme Sürecine Katılan Öğrencilerin Kişisel Özellikleri

\begin{tabular}{lcccrc}
\hline Analiz türü & \multicolumn{2}{c}{ Cinsiyet } & \multicolumn{2}{c}{ Sınıf düzeyi } & Toplam \\
& Kız & Erkek & 3. sınıf & 4. sınıf & \\
\hline Açımlayıcı faktör analizi & 289 & 250 & 260 & 279 & 539 \\
Doğrulayıcı faktör analizi & 197 & 130 & 155 & 172 & 327 \\
\hline
\end{tabular}

Tabloda görüldüğü gibi, açımlayıcı faktör analizine katılan 539 öğrenciden 289'u k1z, 250'si erkektir. Bu öğrencilerin 260'1 3. sınıfta öğrenim görürken, 279’u 4. sınıfta öğrenim görmektedir. Doğrulayıcı faktör analizine katılan 327 öğrencinin ise 197'si kız, 130’u erkektir. Bu öğrencilerin 260'1 3. sınıfta öğrenim görürken, 279'u 4. sınıfta öğrenim görmektedir.

\section{Veri Toplama Araçları}

Araştırmada kültürel mirasa duyarlılık ölçeğinin geliştirilmesi amaçlanmıştır. Bu kapsamda öncelikle madde havuzu oluşturulmuş ve bu madde havuzuna ilişkin uzman görüşüne başvurulmuştur. Daha sonra ise pilot uygulama yapılmış ve ölçek geliştirilmeye hazır hale getirilmiştir.

Ölçeğin geliştirilmesi için yapılan işlemler şu basamaklarda gerçekleştirilmiştir:

- Madde havuzunun oluşturulması: Ölçeğin geliştirme sürecinin ilk aşaması olan bu basamakta öğrencilerin kültürel mirasa duyarlılıklarını ölçebilecek maddelerden oluşan bir havuz hazırlanmıştır. Bu aşamada kültürel mirasa ilişkin alanyazın taranmıştır. Yapılan tarama sonucunda ilkokul öğrencilerinin düzeyine uygun 31 maddelik bir havuz oluşturulmuştur.

- Madde havuzunun uzman görüşüne sunulması: Madde havuzunda yer alan maddeler, Anadolu Üniversitesi'nde görev yapmakta olan 1 ölçme değerlendirme, 2 mimarlık, 2 sosyal bilgiler eğitimi ve 2 sınıf eğitimi alanından olmak üzere toplam 7 uzmanın görüşüne sunulmuştur. Uzman grubunun oluşturulmasında kültürel miras konusunda çalışmaları olma ve ölçek geliştirme konusunda deneyimli olma ölçütleri dikkate alınmıştır. Uzmanlardan maddelerin kültürel mirasa duyarlılığı ölçmeye uygun olup olmadığını ve maddelerin anlaşılır olup olmadığını gerekçeleriyle açıklamaları ayrıca varsa önerilerini belirtmeleri istenmiştir. Uzman görüşleri doğrultusunda 1 maddenin taslak formdan çıkarılmasına karar verilmiştir.

- Pilot çalışmanın yapılması: Araştırma kapsamında hazırlanan 30 maddelik taslak ölçek formu 20 ilkokul öğrencisine uygulanarak anlaşılırlık açısından kontrol edilmiştir. İlkokul öğrencilerinden gelen dönütler doğrultusunda 5 
maddenin yazımı yeniden düzenlenmiştir. Bu bağlamda 30 maddeden ve 4'lü seçenekten oluşan (hiç katılmıyorum, katılmıyorum, katıllyorum, tamamen katılıyorum) taslak likert tipi ölçek formuna son şekli verilerek 539 öğrenci üzerinde uygulaması gerçekleştirilmiştir.

- Veri setinin analize hazırlanması: Araştırmada açımlayıcı faktör analizine başlamadan önce veriler analiz sürecine hazırlanmıştır. Bunun için öncelikle madde puanları standart puanlara çevrilmiş, uç değerler veri setinden çıkarılmıştır. Böylece açımlayıcı faktör analizi 476 kişilik veri seti üzerinden gerçekleşmiştir. Ayrıca kayıp değerler madde ortalamasına bakılarak veri setine eklenmiştir.

\section{Verilerin Analizi}

Araştırma kapsamında geliştirilen ölçeğin geçerli ve güvenilir bir araç olması için birtakım analizlerden yararlanılmıştır. Ölçeğin kapsam geçerliğini sağlamak için uzman görüşüne başvurulmuştur. Ölçeğin yapı geçerliği ise Açımlayıcı Faktör Analizi ile yapılmıştır. Güvenirlik analizleri kapsamında Cronbach Alpha analizi ve maddeler arası korelasyon ortalaması gerçekleştirilmiştir. Ayrıca, maddelerin madde-toplam puan korelasyonları incelenmiş ve t-testi analiziyle de madde ayırt edicilik indeksleri hesaplanmıştır. Ölçeğin alt boyutlarının birbiri ve toplam puanla ilişkisini belirlemek amacıyla korelasyon analizinden yararlanılmıştır. Açımlayıcı faktör analizi ile ortaya konulan ölçek yapısının doğruluğunun sınanması ise Doğrulayıcı Faktör Analizi ile gerçekleştirilmiştir.

Örneklem büyüklüğünün faktör analizi için uygun olup olmadığını belirlemek amacıyla KMO test sonucuna bakılmış ve bu değer .90 olarak hesaplanmıştır. Bu değer örneklem büyüklüğünün faktör analizi için uygun olduğunu göstermektedir (Çokluk, Şekercioğlu \& Büyüköztürk, 2010). Her bir değişkenin çarpıklık ve basıklık değerlerinin kendi standart hatasına bölünmesiyle elde edilen değerin, +1.96 ile -1.96 aralığında değiştiği belirlenmiştir. Normallik sayıltısını test etmek için Barlett Küresellik Testi sonucu veri setinin normallik sayıltısını karşıladığını göstermektedir $(=3345,628, \mathrm{sd}=435, \mathrm{p}<.001)$. Bu değerin yüksek olması maddelerin ilişkili ve faktör analizi için uygun olduğunu göstermektedir (Büyüköztürk, 2010).

\section{Bulgular ve Yorum}

\section{Ölçeğin Yapı Geçerliği ve Güvenirliğine İliş̧kin Bulgular}

Açımlayıcı faktör analizinde değişkenler arasındaki ilişkiler dikkate alınarak faktör bulma işlemi gerçekleştirilir. Bu nedenle kültürel mirasa duyarlılık ölçeğinin faktör yapısını belirlemek amacıyla faktör analizi yapılmıştır. Bu yapıyı belirlemek için öncelikle Kaiser ölçütü gereği özdeğerleri 1'den büyük faktörlerin açıkladığı varyans oranları incelenmiştir. Buna göre ölçeğin 8 faktörlü bir yapı sergileyerek toplam 
varyansın 52.29'unu açıkladığı görülmüştür. Ancak bu ölçüte göre faktör sayısına karar vermede faktörlerin kuramsal olarak anlamlandırılabilmesi de önem taşımaktadır. Yine faktör sayısına karar verebilmek için çizgi grafiğinden yararlanılmıştır (Akbulut, 2010; Çokluk vd., 2010). Çizgi grafiği Şekil 1'de gösterilmiştir.

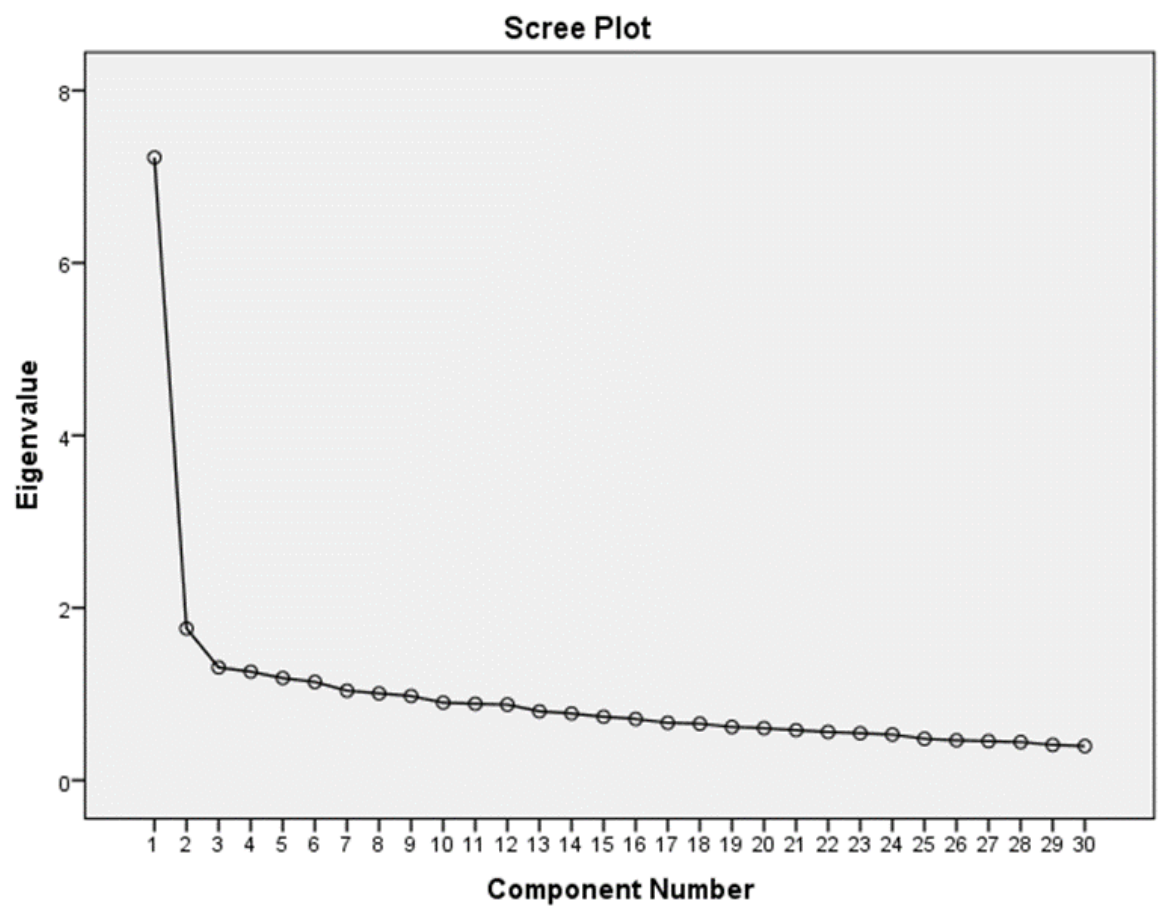

Şekil 1. Kültürel mirasa duyarlılık ölçeğine ilişskin çizgi grafiği.

Şekil 1 incelendiğinde, çizgi grafiğinin eğiminde üçüncü faktörden sonra bir düşüş olduğu görülmektedir. Faktör sayısını belirlemek için çizgi grafiğinde eğimin kaybolmaya başladığı nokta göz önüne alındığında (Çokluk vd., 2010) kültürel mirasa duyarlılık ölçeğinin üç faktörlü bir yapı sergilediği ifade edilebilir.

Kültürel mirasa duyarlılık ölçeğinde bir faktör altında yüksek ilişki veren maddeleri bir araya getirmek için döndürme tekniği kullanılmıştır. Bunun için sosyal bilimlerde sıklıkla tercih edilen dik döndürme tekniklerinden biri olan varimax tekniği kullanılmıştır. Maddelerin yer aldığı faktördeki yük değerinin .45 olması iyi bir ölçüt olarak kabul edilmektedir. Aynı zamanda yüksek iki yük değeri arasındaki farkın en az .10 olması beklenmektedir (Büyüköztürk, 2010). Bu araştırmada ise varimax döndürme sonucunda hangi maddelerin bir faktör altında toplandığını belirlemek için bir maddenin yer aldığı faktördeki yük değerinin en az .45 olması ve maddelerin faktörler altındaki yük değerleri arasında .30 fark olması ölçütleri dikkate alınmıştır. 
Maddeler elendikten sonra üç faktörlü yapıyla sonuçlanan varimax yöntemi ile dik döndürülmüş temel bileşenler analizi sonuçları Tablo 2'de belirtilmiştir.

Tablo 2.

Maddeler Elendikten Sonra Varimax Yöntemi İle Dik Döndürülmüş Temel Bileşenler Analizi Sonuçları

\begin{tabular}{|c|c|c|c|c|c|c|}
\hline \multirow[t]{2}{*}{$\begin{array}{l}\text { Madde } \\
\text { No }\end{array}$} & \multirow{2}{*}{$\begin{array}{c}\text { Yeni } \\
\text { Madde } \\
\text { No }\end{array}$} & \multicolumn{3}{|c|}{$\begin{array}{c}\text { Ölçeğin Döndürme Sonrası Faktör Yük } \\
\text { Değerleri }\end{array}$} & \multirow{2}{*}{$\begin{array}{c}\text { Madde } \\
\text { Toplam } \\
\text { Korelasyonu }\end{array}$} & \multirow[t]{2}{*}{$\begin{array}{c}\text { Ortak Faktör } \\
\text { Varyansı }\end{array}$} \\
\hline & & F1 & F2 & F3 & & \\
\hline M13 & 1 & .736 & & & .48 & .54 \\
\hline M17 & 2 & .669 & & & .44 & .44 \\
\hline M20 & 3 & .652 & & & .47 & .42 \\
\hline M30 & 4 & 609 & & & .47 & .37 \\
\hline M26 & 5 & .590 & & & .51 & .34 \\
\hline M15 & 6 & .551 & & & .47 & .30 \\
\hline M6 & 7 & & .684 & & .35 & .46 \\
\hline M14 & 8 & & .671 & & .34 & .45 \\
\hline M18 & 9 & & .630 & & .42 & .39 \\
\hline M23 & 10 & & .530 & & .43 &, 28 \\
\hline M5 & 11 & & & .747 & .28 & .55 \\
\hline M19 & 12 & & & .637 & .39 & .40 \\
\hline M29 & 13 & & & .586 & .48 & .34 \\
\hline \multicolumn{2}{|c|}{ Özdeğeri } & 3.782 & 1.321 & 1.054 & \multicolumn{2}{|c|}{ Toplam } \\
\hline \multicolumn{2}{|c|}{ Açk. Varyans } & 20.230 & 14.475 & 12.60 & \multicolumn{2}{|c|}{47.355} \\
\hline \multicolumn{2}{|c|}{ Cronbach Alpha } & .75 & .58 & .53 & \multicolumn{2}{|c|}{.79} \\
\hline \multicolumn{5}{|c|}{ KMO } & \multicolumn{2}{|c|}{.85} \\
\hline
\end{tabular}

Tablo 2'de görüldüğü gibi, "Merak Duyma” olan ilk faktörde 6 maddenin yer aldığ1 ve yük değerlerinin .551 ile .736 aralığında değiştiği görülmektedir. Bu maddelerin madde toplam puan korelasyonlarının .47 ile .51 aralığında ortak faktör varyanslarının ise .30 ile .54 aralığında değiştiği belirlenmiştir. "Geleceğe Aktarma" adlı ikinci faktörde ise 4 madde yer almaktadır. Bu maddelerin yük değerleri .530 ile .684 aralığında değişmektedir. Yine bu maddelerin madde toplam puan korelasyonlarının .34 ile .43 aralığında, ortak faktör varyanslarının ise .28 ile .46 aralığında değiştiği görülmüştür. "Koruma" olarak adlandırılan üçüncü faktörde ise yük değerleri .586 ile .747 aralığında değişen üç madde yer almaktadır. Bu maddelerin madde toplam puan korelasyonları .28 ile .48 aralığında değiştiği belirlenirken, ortak faktör varyansının .34 ile .55 aralığında değiştiği belirlenmiştir.

Kültürel mirasa duyarlılık ölçeğinin üç alt faktörü toplam varyansın \%47.335'ini açıklamaktadır. Ölçeğin KMO değeri, .85 olup, Bartlett Küresellik Testi sonucunun .01 düzeyinde anlamlı olduğu görülmektedir $\left[\mathrm{X}^{2}=1090.218 . \mathrm{sd}=78 . \mathrm{p}<.001\right)$. 
Ölçeğin güvenirlik analizleri sonucunda tamamına ilişkin alpha katsayısı .79'tur. "Merak Duyma" alt boyutunun alpha katsayıs1 .75, "Geleceğe Aktarma" alt boyutunun .58 ve "Koruma" alt boyutunun ise .53 'tür. Görüldüğ̈̈ gibi, "Geleceğe Aktarma" ve "Koruma" alt boyutlarında madde sayısının az olmasından kaynaklı olarak (Balc1 \& Ahi, 2015/2017; Şencan, 2005; Sönmez \& Alacapınar, 2016) güvenirlik katsayıları düşük aralıkta $(.40<\alpha<.60)$ (Özdamar, 2004) çıkmıştır. Bu nedenle bu alt boyutlardaki maddeler için maddeler arası korelasyon ortalaması hesaplanmıştır (Balcı \& Ahi, 2015/2017). Hesaplanan bu değerler Tablo 3'te sunulmuştur.

Tablo 3.

Maddeler Arası Korelasyon Değerleri

\begin{tabular}{lllll}
\hline Boyutlar & Ortalama & Minimum & Maksimum & Madde sayıs \\
\hline $\begin{array}{l}\text { Geleceğe aktarma boyutundaki } \\
\text { maddeler arası korelasyon }\end{array}$ & .260 & .200 & .330 & 4 \\
$\begin{array}{l}\text { Koruma boyutundaki maddeler } \\
\text { arası korelasyon }\end{array}$ & .277 & .211 & .382 & 3 \\
\hline
\end{tabular}

Tabloda görüldüğü gibi, maddeler arası korelasyon ortalaması değeri geleceğe aktarma boyutu için .260 olarak hesaplanmıştır. Bu boyutta değerlerin .200 ile .330 arasında değiştiği belirlenmiş̧ir. Koruma boyutunda ise ortalama değer .277 olarak bulunmuştur. Bu boyuttaki değerler ise .211 ile .382 arasında yer almaktadır. Briggs ve Cheek (1986) bu değerlerin .2 ile .4 arasında değişmesi gerektiğini önermektedir (Balcı \& Ahi, 2015/2017). Buna göre elde edilen değerler göz önünde bulundurulduğunda bu boyutların da güvenilir olduğu söylenebilir.

Güvenirlik analizleri için yapılan bir diğer analiz ise alt $\% 27$ ve üst $\% 27$ 'lik gruplara ait bağımsız $t$ testidir. Buna göre verilerin toplandığı bireylerin 13 maddeden aldıkları toplam puanlar, büyükten küçüğe doğru sıralanmıştır. Bu sıralamaya göre alt $\% 27$ 'lik grup ile üst \%27'lik grupların puanları bağımsız gruplar $t$ testi ile incelenmiş ve ulaşılan bulgulara Tablo 4 'te yer verilmiştir.

Tablo 4.

Alt \%27'lik Ve Üst \%27'lik Gruplara Ilişkin Bağımsız Gruplar T Testi Sonuçları

\begin{tabular}{lllllc}
\hline Madde & Grup & N & X & SS & t \\
\hline M5 & Üst\%27 & 128 & 3.94 & .22 & 9.096 \\
M1t\%27 & Alt\%27 & 128 & 3.42 & .60 & \\
& Üst\%27 & 128 & 3.76 & .42 & 10.269 \\
M13 & Alt\%27 & 128 & 2.90 & .84 & \\
& Üst\%27 & 128 & 3.91 & .30 & 14.961 \\
M14 & Alt\%27 & 128 & 2.77 & .80 & \\
& Üst\%27 & 128 & 3.80 & .41 & 8.392 \\
& Alt\%27 & 128 & 3.23 & .64 &
\end{tabular}




\begin{tabular}{llllll} 
M15 & $\ddot{U}$ st\%27 & 128 & 3.96 & .17 & 14.514 \\
M17 & Alt\%27 & 128 & 3.06 & .68 & \\
& Üst\%27 & 128 & 3.92 & .26 & 12.166 \\
M18 & Alt\%27 & 128 & 2.97 & .83 & \\
& Üst\%27 & 128 & 3.85 & .37 & 14.172 \\
M19 & Alt\%27 & 128 & 2.68 & .84 & \\
& Üst\%27 & 128 & 3.99 & .08 & 9.547 \\
M20 & Alt\%27 & 128 & 3.46 & .61 & \\
& Üst\%27 & 128 & 3.94 & .22 & 14.123 \\
M23 & Alt\%27 & 128 & 2.91 & .79 & \\
& Üst\%27 & 128 & 3.85 & .37 & 11.984 \\
M26 & Alt\%27 & 128 & 2.92 & .79 & \\
& Üst\%27 & 128 & 3.89 & .33 & 13.711 \\
M29 & Alt\%27 & 128 & 2.76 & .86 & \\
& Üst\%27 & 128 & 4.00 & .00 & 10.471 \\
M30 & Alt\%27 & 128 & 3.44 & .59 & \\
& Üst\%27 & 128 & 3.89 & .32 & 14.503 \\
\hline
\end{tabular}

${ }^{*} p<.001$

Tablo 4'te görüldüğü gibi 13 maddeye ilişkin alt grup ortalamalarının 2.68 ile 3.46 aralığında, üst grup ortalamalarının ise 3.85 ile 4.00 aralığında değiştiği görülmektedir. Alt ve üst gruplara ilişkin standart sapma değerleri ise .00 ile .86 aralığında, maddelere ilişkin t değerlerinin 8.392 ile 14.961 aralığında değiştiği ve tüm maddelerin grupları anlamlı bir şekilde ayırt edebildiği belirlenmiştir $(\mathrm{p}<.001)$.

Kültürel mirasa duyarlılık ölçeğinin toplam puan ve alt ölçeklerine ilişkin korelasyon matrisi Tablo 5'te sunulmuştur.

Tablo 5.

Ölçek Toplam Puan Ve Alt Ölçeklerine İlişkin Korelasyon Matrisi

\begin{tabular}{llll}
\hline Faktörler & $\mathbf{1}$ & $\mathbf{2}$ & $\mathbf{3}$ \\
\hline 1.Merak duyma & 1 & $.427^{* *}$ & $.402^{* *}$ \\
2. Geleceğe aktarma & $.427^{* *}$ & 1 & $.401 * *$ \\
3. Koruma & $.402^{* *}$ &. $.401^{* *}$ & 1 \\
4. Toplam Puan & $.882^{* *}$ & $.764^{* *}$ & $.635^{* *}$ \\
\hline
\end{tabular}

$\mathrm{N}=476, * * \mathrm{p}<0.01$

Tablo 5'te görüldüğü gibi, kültürel mirasa duyarlılık ölçeğinde yer alan alt ölçeklerin birbiriyle ve toplam puanla anlamlı ilişkiler göstermektedir. Merak duyma alt ölçeği geleceğe aktarma ile .43 , koruma ile .40; geleceğe aktarma ölçeği ise koruma ile .40 değerinde anlamlı ilişki göstermektedir. Merak duyma toplam puanla .88, geleceğe aktarma toplam puanla .76 ve koruma toplam puanla .63 değerinde anlamlı ilişki gösterdiği sonucuna ulaşılmıştır. 


\section{Ölçeğin Doğrulayıcı Faktör Analizine İlişkin Bulgular}

İlkokul üçüncü ve dördüncü sınıf öğrencilerinin kültürel mirasa duyarlılıklarını ortaya koymak amacıyla açımlayıcı faktör analizi ile geliştirilen 13 maddeli ve 3 faktörlü Kültürel Mirasa Duyarlılık Ölçeği'nin model olarak doğrulanıp doğrulanmadığını test etmek amacıyla doğrulayıcı faktör analizi uygulanmıştır. Doğrulayıcı faktör analizi, ölçeğin geçerlik ve güvenirlik çalışmaları yapıldıktan sonra 327 öğrenci ile gerçekleştirilmiştir. Ölçeğin doğrulanması için kovaryans matrisi ve en çok olabilirlik yönteminden yararlanılmıştır. Yapılan analiz sonucunda faktörler ve gözlenen değişkenler arasındaki ilişkiler ve gözlenen değişkenlerin hata varyansları Şekil 2'de gösterilmiştir.

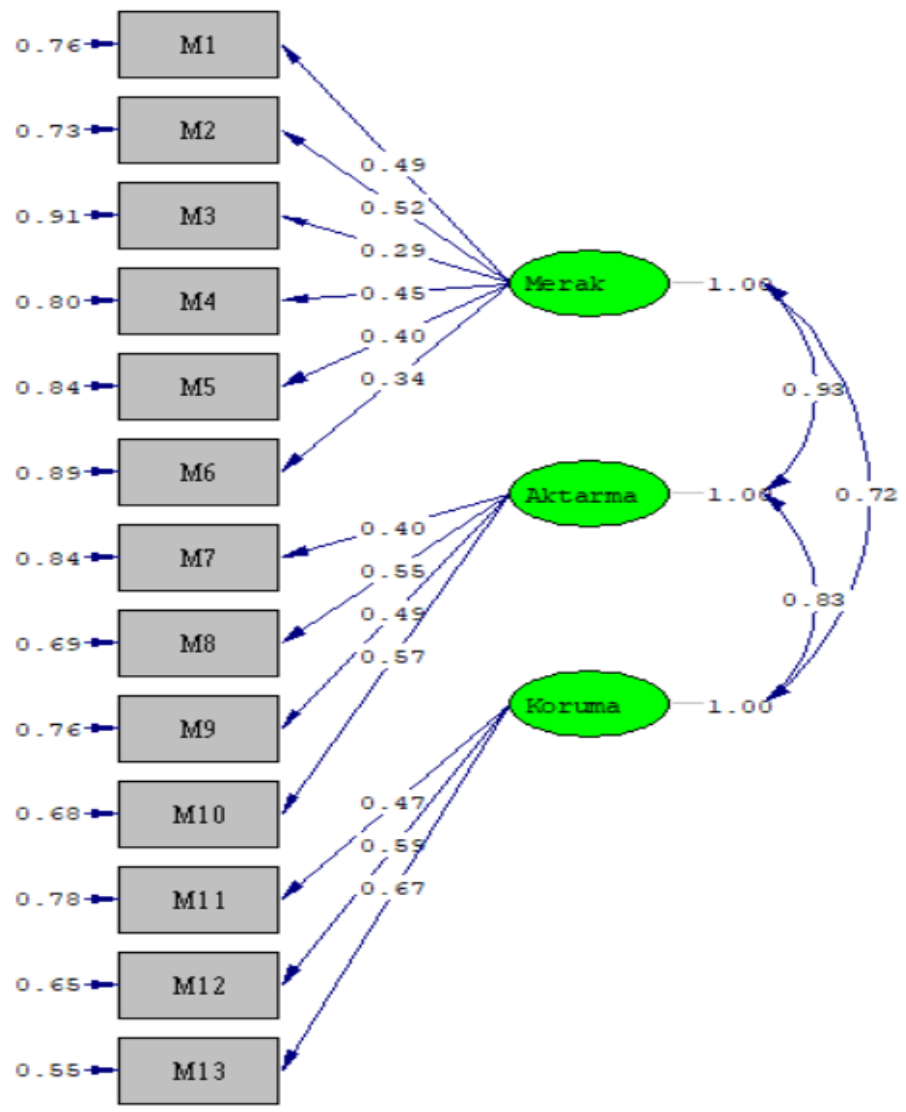

Şekil 2. Ölçeğin doğrulayıcı faktör analizi sonucunda gözlenen değişkenler arasındaki ilişkiler ve hata varyansları. 
Elde edilen ölçme modelindeki Lambdax, $\mathrm{t}$ ve açıklayıcılık varyansı değerleri Tablo 6'da sunulmuştur.

Tablo 6.

Kültürel Mirasa Duyarlılık Ölçeği'nin Lambdax, $t$ ve Açıklayıcılık Varyans Değerleri

\begin{tabular}{|c|c|c|c|c|}
\hline Faktörler & Maddeler & $\lambda$ & $\mathbf{t}$ & $\mathbf{R}^{2}$ \\
\hline \multirow{6}{*}{ 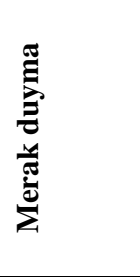 } & 1 & 0.49 & 7.92 & 0.24 \\
\hline & 2 & 0.52 & 8.35 & 0.27 \\
\hline & 3 & 0.29 & 4.59 & 0.09 \\
\hline & 4 & 0.45 & 7.18 & 0.20 \\
\hline & 5 & 0.40 & 6.28 & 0.16 \\
\hline & 6 & 0.34 & 5.30 & 0.11 \\
\hline \multirow{4}{*}{ 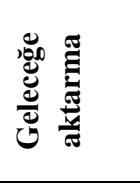 } & 7 & 0.40 & 6.58 & 0.16 \\
\hline & 8 & 0.55 & 9.28 & 0.31 \\
\hline & 9 & 0.49 & 8.14 & 0.24 \\
\hline & 10 & 0.57 & 9.50 & 0.32 \\
\hline \multirow{3}{*}{ : } & 11 & 0.47 & 7.44 & 0.22 \\
\hline & 12 & 0.59 & 9.59 & 0.35 \\
\hline & 13 & 0.67 & 10.83 & 0.45 \\
\hline
\end{tabular}

Geliştirilen ölçeğin ölçme modelinde, üçüncü maddenin hata varyansının yüksek olduğu ortaya çıkmıştır. Ancak, tabloda da görüldüğü gibi, t değerleri kontrol edildiğinde bu değerlerin .01 düzeyinde anlamlı sonucuna ulaşılmıştır. Bu nedenle söz konusu maddenin ölçme modelinde kalmasına karar verilmiştir. Tablo 5 'te görüldüğü gibi, faktörler ve gözlenen değişkenler arasındaki ilişkilerin merak duyma faktöründe .29 ile .52; geleceğe aktarma faktöründe .40 ile .57 ve koruma faktöründe .47 ile .67 arasında değiştiği görülmüştür. Ayrıca maddelerin t değerleri 4.59 ile 10.83 aralığında değişmekte olup .01 düzeyinde anlamlıdır. Maddeler incelendiğinde en yüksek açıklanan varyans .45 ile 13'ken, en düşük açıklanan varyans .09 ile 3'tür.

Kültürel mirasa duyarlılık ölçeği için elde edilen uyum indeksleri ve uyum indeksleri için kabul ölçütleri Tablo 7'de sunulmuştur.

Tablo 7.

Kültürel Mirasa Duyarlılık Ölçeği’nin Uyum İndeksleri

\begin{tabular}{llll}
\hline İndeksler & Model değerleri & İyi Uyum & Kaynaklar \\
\hline$\chi^{2} / \mathrm{df}$ & 1.16 & $0 \leq \chi^{2} / \mathrm{df} \leq 2$ & (Tabachnick ve Fidel, 2001) \\
RMSEA & 0.06 & $\leq .05$ & (Sümer, 2000) \\
SRMR & 0.056 & $<.08$ & (Brown, 2006; Akt; Çokluk ve \\
& & & diğerleri, 2010) \\
NFI & 0.89 & $>.90$ iyi uyum & (Sümer, 2000) \\
NNFI & 0.92 & $0.95 \leq$ NNFI $\leq 1.00$ & (Tabachnick ve Fidel, 2001)
\end{tabular}




\begin{tabular}{llll} 
GFI & 0.93 & $>.85$ & \\
& & (Jöreskog ve Sörbom, 1996, Akt; \\
& Y1lmaz ve Çelik, 2009) \\
AGFI & 0.91 & $>.85$ & (Jöreskog ve Sörbom, 1996, Akt; \\
& & Y1lmaz ve Çelik, 2009) \\
\hline
\end{tabular}

Ölçek modelinin doğrulayıcı faktör analizi sonuçlarına göre uyum indeksleri ve modifikasyon indeksi sonuçları incelenmiştir. Bu analiz sonuçlarına göre $\chi 2=143.86$ $(\mathrm{sd}=62, \mathrm{p}<.001), \chi 2 / \mathrm{sd}$ değeri $(1.16), \mathrm{RMSEA}=.06, \mathrm{SRMR}=0.056, \mathrm{NFI}=0.89$, NNFI $=.92, \mathrm{GFI}=0.93$ ve $\mathrm{AGFI}=0.91$ 'dir. Bu uyum istatistikleri modelin iyi bir uyuma sahip olduğunu göstermektedir (Kline, 2005; Sümer, 2000; Tabachnick \& Fidell, 2001). Bu değerlere dayalı olarak kültürel mirasa duyarlılık ölçeğinin açımlayıcı faktör analizi sonucunda elde edilen faktör yapısının doğrulandığı ortaya konulmuştur.

\section{Tartışma, Sonuç ve Öneriler}

Çalışmada ilkokul öğrencilerinin kültürel mirasa duyarlılıklarını ölçmeye yönelik geçerli ve güvenilir bir ölçme aracının geliştirilmesi amaçlanmıştır. Yapılan geçerlik ve güvenirlik analizleri kapsamında üç boyutlu dörtlü likert tipi (1: Hiç katılmıyorum, 2: Katılmıyorum, 3: Katılıyorum, 4: Kesinlikle katılıyorum) bir ölçme aracı geliştirilmiştir. Elde edilen Kültürel Mirasa Duyarlılık Ölçeği "Merak Duyma", "Geleceğe Aktarma" ve "Koruma" alt boyutlarından oluşmaktadır. Ölçekten alınabilecek en yüksek puan 52 iken, en düşük puan 13'dür. Bu durumda 13-25 puan arası düşük, 26-38 puan arası orta ve 39-52 puan arası ise yüksek düzeyde kültürel mirasa duyarlılığa işaret etmektedir. Ölçekten alınan puan yükseldikçe kültürel mirasa duyarl1l1k yükselmektedir.

$\mathrm{Bu}$ ölçekte kültürel mirasa duyarlılığın alt boyutlarından biri olarak "merak duyma" ortaya çıkmıştır. Öğrencilerin kültürel mirasa merak duymaları ve ilgilenmelerinin temel yolu onlara kültürel mirasla etkileşime girecekleri aktif deneyimler sağlamaktır. Öğrencilere yalnızca sözel olarak kültürel mirası tanıtmak ve onların pasif dinleyici olarak kaldıkları süreçler çok fazla işlevsel görülmemektedir (Ivon \& Kuscevic, 2013). Alanyazında kültürel miras eğitiminde alan gezilerinin, oyunların ve çocukların ilgilerini çekecek ve onların aktif olacağı etkinliklerin eğlenerek öğrenmeyi sağlama bakımından etkili olduğu belirtilmektedir (Aerila \& diğerleri, 2016; Dönmez \& Yeşilbursa, 2014; Henderson \& Atencio, 2007). Bu bağlamda merak duymanın kültürel miras eğitiminde önemli bir unsur olduğu söylenebilir. Bu çalışmada kültürel mirasa duyarlılık ölçeğinin boyutlarından biri olarak belirlenen merak duyma, kültürel miras eğitimiyle ilgili alanyazınla da örtüşmektedir.

Kültürel miras eğitiminde amaç, öğrencilerin yalnızca tarihi yerler ve nesneler hakkındaki bilgilerini artırmak değil, aynı zamanda bu tarihi nesneler ve geleneklere ilişkin bir duyarlılık aşılamak ve böylece onları bu mirasın korunmasından ve geleceğe aktarılmasından aktif olarak sorumlu kılmaktır (Barghi vd., 2013). Bu 
bağlamda "koruma" ve "geleceğe aktarma", kültürel miras eğitiminin iki önemli bileşeni olarak ortaya çıkmaktadır. Gürdoğan Bayır ve Çengelci Köse’nin (2019) ortaokul öğrencilerinin kültürel miras ve korunmasına ilişkin görüşlerini araştırdıkları çalışmanın sonuçları, öğrencilerin kültürel mirasın önemli olduğunu ve korunması gerektiğini düşündüklerini ortaya koymaktadır. Alanyazında kültürel mirasla ilgili olarak öğretmen adaylarıyla gerçekleştirilen çalışmaların sonuçları da öğretmen adaylarının kültürel mirasın korunması ve gelecek kuşaklara aktarılması gerektiğini düşündüklerini göstermektedir (Selanik Ay \& Kurtdede Fidan, 2013; Sidekli \& Karaca, 2013). Bu çalışmada da "koruma" ve "geleceğe aktarma" kültürel mirasa duyarlılık ölçeğinin boyutları olarak ortaya çıkmıştır.

Kültürel Mirasa Duyarlılık Ölçeği'nin geliştirilmesi sürecinde elde edilen geçerlik ve güvenirlik değerleri ölçeğin kullanabilir olduğunu ortaya koymaktadır. Ölçekte yer alan üç boyut toplam varyansın \%47.335'ini açıklamaktadır. Açıklanan varyans değerinin faktör analizlerinde önemli olarak görülmektedir. Bu değer "bir faktör ya da bileşenin içinde bulunduğu madde öbeğinin ne kadarına katkı yaptığını belirten ölçü” (Erkuş, 2014) olarak tanımlanmakta ve ölçülmek istenen özelliğin ne düzeyde açıkladığını belirtmektedir. Çok faktörlü ölçeklerde \%40-\%60 arasında varyansın açıklanması yeterli görüldüğünden (Dunteman, 1989; Aktaran Akbulut, 2008; Çokluk vd., 2010) geliştirilen ölçek, öğrencilerin kültürel mirasa duyarlılıklarını ölçmek için yeterli bulunmuştur. $\mathrm{Bu}$ bağlamda, ölçeğin öğrencilerin kültürel mirasa duyarlılıklarını kabul edilebilir biçimde ölçtüğü söylenebilir.

Ölçek geliştirme sürecinde açımlayıcı faktör analizinde faktörlerde yer alan maddelerin faktör yüklerinin .530 ve üzerinde değer aldığı belirlenmiştir. Alanyazında .32 ve üzerinde değer alması gerektiği ele alındığında (Tabachnick \& Fidell, 2001) ölçekte yer alan maddelerin faktör yük değerlerinin oldukça iyi düzeyde olduğu ifade edilebilir. Başka bir deyişle, ölçekte yer alan maddelerin faktörle ilişkisi iyi düzeydedir.

Kültürel Mirasa Duyarlılık Ölçeği'nin Alpha katsayısı .79 olarak belirlenmiştir. Merak duyma faktörünün Cronbach Alpha katsayısı .75, geleceğe aktarma faktörünün katsayısı .58, koruma faktörünün katsayısı ise .53 olarak bulunmuştur. Ölçeğin tümüne ve merak duyma boyutuna ilişkin değerler alanyazında kabul gören .70 değerinin (Büyüköztürk, 2010) üzerindedir. Ancak geleceğe aktarma ve koruma faktörleri bu değerin altındadır. Alanyazında .40 ve altının güvenilir olmadığı, bu değerlerin ise düşük düzeyde $(.40<\alpha<.60)$ güvenirliğe sahip olduğu belirtilmektedir (Özdamar, 2004). Ayrıca alanyazında faktördeki madde sayısının az olması durumunda bu değerin düşük olabileceği ifade edilmektedir. Alpha değeri ölçekteki madde sayısı ile yakından ilişkilidir (Balcı \& Ahi, 2015; 2017; Sönmez \& Alacapınar, 2016; Şencan, 2005). Çünkü madde sayısının az olması durumunda Cronbach Alpha gerçek güvenirlikten daha düşük sonuçlar verebilmektedir (Kula Kartal \& Mor Dirlik, 2016). Bu durumda maddeler için maddeler arası korelasyon ortalamasının hesaplanması uygundur (Balc1 \& Ahi, 2015/2017). Buna göre geleceğe aktarma 
boyutunda bu değer .260, koruma boyutunda ise .277 olarak bulunmuştur. Elde edilen bu değerler alanyazında Briggs ve Cheek (1986) tarafından belirtilen .2 ile .4 değerleri arasında olmasından dolayı bu boyutların güvenilir olduğu ifade edilebilir (Balcı ve Ahi, 2015; 2017). Buna ek olarak güvenirlik analizleri kapsamında \%27'lik alt grup ve $\% 27$ 'lik üst grup puanları bağımsız gruplar t testi yapılmıştır. Bu testin sonucunda ise ölçekte yer alan maddelerin grupları anlamlı düzeyde ayırt ettiği belirlenmiştir. Ölçekte yer alan maddelerin madde toplam korelasyonlarının .28 ile .51 aralığında değiştiği görülmektedir. Ayrıca ölçekte yer alan 1 maddenin madde toplam korelasyonun $.28,3$ maddenin .30 ile .40 aralığında ve 9 maddenin ise .40 ve üzerinde olduğu belirlenmiştir. Ölçek geliştirme sürecinde madde toplam korelasyonlarının $.20-.30$ arasında olduğunda maddelerin zorunlu olması durumunda teste alınabileceği ifade edilmektedir. Ölçekte yer alan bir madde bu nedenle ölçeğe alınmıştır. Madde toplam puan korelasyonu .30 ve üzerinde olan maddelerin bireyleri iyi ayırt ettiği, .40 ve üzerinde olması durumunda ise maddelerin çok iyi bir ayırt edici olduğu ifade edilmektedir (Büyüköztürk, 2018). Bu kapsamda bağımsız gruplar t testi sonuçları ve madde toplam korelasyonlarının geliştirilen ölçek için yeterli düzeyde olduğu belirlenmiştir.

Araştırmada ölçek geliştirme çalışma için yapılan korelasyon analizinde alt boyutların toplamla sırasıyla $.88, .76$ ve .63 düzeyinde anlamlı ilişkilere sahip olduğu belirlenmiştir. Ölçekteki alt boyutların korelasyon değerleri ise .40 ile .43'tür. Ölçek geliştirme çalışmalarında alt boyutların toplam puanla düşük ilişki göstermesi (.30 ve altı) ve alt boyutların birbiri ile yüksek ilişki göstermesi (.90 ve üstü) sorun olarak karşımıza çıkmaktadır. Alt boyutların toplam puanla düşük ilişki göstermesi bu boyutların ölçekle aynı şeyi ölçmediğini gösterirken, alt boyutların birbiri ile yüksek ilişki göstermesi çoklu bağlantı sorununa işaret etmektedir (Çokluk vd., 2010). Bu bağlamda üç faktörden bulunan korelasyon değerleri, alt boyutların birbirinden ayrı yapıları ölçtüğünü ve tüm ölçeğin bileşenleri olduğunu göstermektedir.

Ölçeğin doğrulayıcı faktör analizi sonuçlarına göre $\chi 2=143.86(\mathrm{sd}=62, \mathrm{p}<.001)$, $\chi 2 /$ sd değeri (1.16), RMSEA $=.06, \mathrm{SRMR}=0.056, \mathrm{NFI}=0.89, \mathrm{NNFI}=.92, \mathrm{GFI}=0.93$ ve $\mathrm{AGFI}=0.91$ 'dir. $\mathrm{Bu}$ uyum istatistikleri modelin iyi bir uyuma sahip olduğunu göstermektedir (Kline, 2005; Sümer, 2000; Tabachnick \& Fidell, 2001). Bu değerlere dayalı olarak kültürel mirasa duyarlılık ölçeğinin açımlayıcı faktör analizi sonucunda elde edilen faktör yapısının doğrulandığı ortaya konulmuştur.

Sonuç olarak, bu araştırmada geçerliği ve güvenilirliği farklı teknikler kullanılarak ortaya konularak "merak duyma", "geleceğe aktarma" ve "koruma" boyutlarından oluşan 3 faktörlü ve 13 maddelik likert tipi bir ölçme aracına ulaşılmıştır. Kültürel Mirasa Duyarlılık Ölçeği olarak adlandırılan bu ölçeğin elde edilen 3 faktörlü yapısının doğrulandığı sonucuna ulaşılmıştır. Yapılan bu analizler kapsamında ölçeğin, ilkokul öğrencilerinin kültürel mirasa duyarlılıklarını ölçmede kabul edilebilir düzeyde geçerli ve güvenilir olduğu ortaya çıkmıştır. Bu bulgulara göre, bu ölçek farklı araştırmalarda kullanılabilir. Ayrıca ortaokul düzeyinde kullanılabilmesi 
için geçerlik ve güvenirlik çalışmaları yapılabilir. Buna ek olarak bu araştırma, ölçek geliştirme araştırması ile sınırlı olmasından dolayı bu ölçek kullanılarak betimsel ve ilişkisel çalışmalar gerçekleştirilebilir.

\section{Çıkar Çatışması ve Etik Bildirimi}

Araştırma için gerekli etik kurul onayının Anadolu Üniversitesi Sosyal ve Beşeri Bilimler Bilimsel Araştırma ve Yayın Etiği Kurulu yazısı ile 19866 protokol numarasıyla alındığını, araştırmanın tüm süreçlerinde etik kurallara uyulduğunu beyan ederiz.

\section{Kaynakça}

Aerila, J. A., Rönkkö, M. L., \& Grönman, S. (2016). Field trip to a historic house museum with preschoolers: Stories and crafts as tools for cultural heritage education. Visitor Studies, 19(2), 144-155. https//doi.org/10.1080/10645578.2016.1220187

Akbulut, Y. (2008). Exploration of the attitudes of freshman foreign language students toward using computers at a Turkish state university. The Turkish Online Journal of Educational Technology TOJET, 7(1), 18-31.

Akbulut, Y. (2010). Sosyal bilimlerde SPSS uygulamaları. İdeal Kültür Yayıncılık.

Avcı, M., \& Memişoğlu, H. (2016). Kültürel miras eğitimine ilişkin sosyal bilgiler öğretmenlerinin görüşleri. Ilköğretim Online, 15(1), 104-124. https//doi.org/10.17051/io.2016.42123

Barghi, R., Zakaria, Z., Hamzah, A., \& Hashim, N. H. (2017). Heritage education in the primary school standard curriculum of Malaysia. Teaching and Teacher Education, 61, 124-131. https//doi.org/10.1016/j.tate.2016.10.012

Blake, J. (2000). On defining the cultural heritage. The International and Comparative Law Quarterly, 49(1), 61-85.

Büyüköztürk, Ş. (2010). Sosyal bilimler için veri analizi el kitabı. (12. bask1). Pegem Akademi.

Curtis, R., \& Seymour, C. (2004). Louisiana heritage education program and heritage in the classroom: children's attitudes towards culturel heritage. Journal of Social Studies Research, 28(2), 20-24.

Chen, G. M., \& Starosta, W. J. (2000). The development and validity of the Intercultural Sensitivity Scale. Paper presented at the annual meeting of National Communication Association, Seattle, WA.

Çengelci, T. (2012). Sosyal bilgiler öğretim programında somut olmayan kültürel mirasın yeri. Uludă̆ Üniversitesi Ĕ̈itim Fakültesi Dergisi, 25(1), 185-203.sswx 
Çokluk, Ö., Şekercioğlu, G., \& Büyüköztürk, Ş. (2010). Sosyal bilimler için çok değişkenli istatistik. spss ve lisrel uygulamaları. Pegem A Yayıncılık.

Çulha Özbaş, B. (2009). İlköğretim sosyal bilgiler derslerinde kültürel miras eğitimi. M. Safran. (Ed.), Sosyal Bilgiler Eğitimi (s. 702-718) içinde. Pegem Akademi.

Darian Smith, K. \& Pascoe,C. (2013). Children, childhood and cultural hertiage. Routledge Taylor \& Francis Group.

Dönmez, C., \& Yeşilbursa, C. C. (2014). Kültürel miras eğitiminin öğrencilerin somut kültürel mirasa yönelik tutumlarına etkisi. İlköğretim Online, 13(2), 425-442.

Ekiz, D. (2009). Bilimsel araştırma yöntemleri. (Geliştirilmiş 2. baskı). Anı Yayıncılık.

Erkuş, A. (2014). Psikolojide ölçme ve ölçek geliştirme-I: temel kavramlar ve işlemler. (2. bask1). Pegem Akademi.

Gürdoğan Bayır, Ö., \& Çengelci Köse, T. (2019). Kültürel miras ve korunmasına ilişkin ortaokul öğrencilerinin görüşleri. Kastamonu Eğitim Dergisi, 27(4), 1827-1840. https//doi.org/10.24106/kefdergi.3393

Gürel, D., \& Çetin, T. (2019). Intangible cultural heritage attitude scale: validity and reliability study. Bartin University Journal of Faculty of Education, 8(1), 82-102. https//doi.org/10.14686/buefad.465604

Güvenç, B. 2002. Insan ve kültür. (9. basım). Remzi Kitabevi.

Halaç, H. H., \& Demir, İ. (2017). Toplumsal hafızamız kültürel mirasımız. Journal of International Social Research, 10(52), 1141-1145. https//doi.org/10.17719/jisr.2017.1993

Halaç, H. H., Mokrane, H., \& Turan, S. (2019). Tömer öğrencilerinin kültürel miras ve koruma farkındalığı. Eskişehir Anadolu Üniversitesi örneklemi. Journal of Awareness, 4(2), 185 204. https//doi.org/10.26809/joa.4.015

Henderson, T. Z., \& Atencio, D. J. (2007). Integration of play, learning, and experience: What museums afford young visitors. Early Childhood Education Journal, 35(3), 245-251. https//doi.org/10.1007/s10643-007-0208-1

Ivon, H., \& Kuscevic, D. (2013). School and the cultural-heritage environment: pedagogical, creative and artistic aspects. CEPS Journal, 3(2), 29-50.

Keskin, Y., \& Öğretici, B. (2013). Sosyal bilgiler dersinde" duyarlılık" değerinin etkinlikler yoluyla kazandırılması: nitel bir araştırma. Değerler Eğitimi Dergisi, 11(25), 143-181.

Kline, R. B. (2005). Principles and practise of structural equation modeling. Guilford Publications. 
Kula Kartal, S., \& Mor Dirlik, E. (2016). Geçerlik kavramının tarihsel gelişimi ve güvenirlikte en çok tercih edilen yöntem: cronbach alfa katsayısı. Abant İzzet Baysal Üniversitesi Eğitim Fakültesi Dergisi, 16(4), 1865-1879.

Milli Eğitim Bakanlığı. (2018). Sosyal bilgiler dersi öğretim programı (İlkokul ve ortaokul 4, 5, 6 ve 7. sinuflar). http://mufredat.meb.gov.tr/ProgramDetay.aspx?PID=354

Oğuz, E. S. (2011). Toplum bilimlerinde kültür kavramı. Hacettepe Üniversitesi Edebiyat Fakültesi Dergisi, 28 (2), 123-139.

Oğuz, Ö. (2008). Unesco ve insanlığın sözlü ve somut olmayan mirası başyapıtları. Millî Folklor, 20(78), 5-11.

Özdamar, K. (2004). Paket programlar ile istatistiksel veri analizi. Kaan Kitabevi, Eskişehir.

Pallant, J. (2017). SPSS kullanma kılavuzu SPSS ile adım adım veri analizi. S. Balcı ve B. Ahi (Çev.) Anı Yayıncılık. (Özgün Çalışma: 2015).

Ruddock, H.C. \& Turner, S. (2007) Developing cultural sensitivity: nursing students' experiences of a study abroad programme. Journal of Advanced Nursing, 59(4), 361-369.

Selanik Ay, T., \& Kurtdede Fidan, N. (2013). Öğretmen adaylarının" kültürel miras" kavramına ilişkin metaforları. Electronic Turkish Studies, 8(12), 1135-1152. https//doi.org/10.7827/TurkishStudies.5982

Sidekli, S., \& Karaca, L. (2013). Sosyal bilgiler öğretiminde yerel kültürel miras ögelerinin kullanımına ilişkin öğretmen adayı görüşleri. Gaziosmanpaşa Bilimsel Araştırma Dergisi, 5, 20-38.

Somut Olmayan Kültürel Mirasın Korunması Sözleşmesi (2003). https://teftis.ktb.gov.tr/TR264414/somut-olmayan-kulturel-mirasin-korunmasi-sozlesmesi.html adresinden 12 Eylül 2020 tarihinde alındi.

Sönmez, V., \& Alacapınar, F. D. (2016). Sosyal bilimlerde ölçme aracı hazırlama. Anı Yayınc1lik.

Sümer, N. (2000). Yapısal eşitlik modelleri: temel kavramlar ve örnek uygulamalar. Türk Psikoloji Yazılarl, 3(6), 49-74.

Şencan, H. (2005). Sosyal ve davranışsal ölçümlerde güvenilirlik ve geçerlilik. (1.baskı). Seçkin Yayınc1lik.

Tabachnick, B. G., \& Fidell, L. S. (2001). Using multivariate statistics. AllynveBacon, Inc.

UNESCO. (1972). Convention concerning the protection of the world cultural and natural heritage. Adopted by the General Conference at its seventeenth session Paris, 16 november 1972. Retrieved July 15, 2020 from https://whc.unesco.org/archive/convention-en.pdf 
UNESCO. (2003). Convention fort he Safeguarding of the Intangible Cultural Heritage, (MISC/2003/CLT/CH/14), Paris, 17 October. Retrieved July 15, 2020 from https://ich.unesco.org/en/convention.

UNESCO. (2003). Somut olmayan kültürel mirasın korunmast sözleşmesi. https://ich.unesco.org/doc/src/00009-TR-PDF.pdf adresinden 30 Kasim 2020 tarihinde alındi.

Vecco, M. (2010). A definition of cultural heritage: From the tangible to the intangible. Journal of Cultural Heritage, 11(3), 321-324.

Yeşilbursa, C. C. (2011). Sosyal bilgilerde miras eğitiminin öğrencilerin somut kültürel mirasa karşı tutumlarına ve akademik başarılarına etkisi (Tez No. 298403) [Doktora tezi, Gazi Üniversitesi-Ankara]. Yükseköğretim Kurulu Başkanlığı Ulusal Tez Merkezi.

Yılmaz, V., \& Çelik, E. H. (2009). Lisrel ile yapısal eşitlik modellemesi-I: temel kavramlar, uygulamalar, programlama. Pegem Yayıncılık.

\section{Extended Abstract}

Culture can be defined as savings of a society. The historical and social dimension of culture reflect its learnability and continuity rather than staying within a certain discipline (Oğuz, 2011). Practices planned in cultural heritage education will be effective in raising awareness of cultural heritage in students (Gürdoğan Bayır \& Çengelci Köse, 2019). For this reason, it is important to develop a measurement tool that will evaluate students 'sensitivity to cultural heritage in determining the effect of different educational practices on students' sensitivity to cultural heritage. There are some scales in the literature such as cross-cultural sensitivity scale (Chen \& Starosta, 2000); cultural heritage attitude scale (Curtis \& Seymour, 2004), concrete cultural heritage attitude scale (Yeşilbursa, 2011), intangible cultural heritage attitude scale (Gürel \& Çetin, 2019). However, in the literature, there is not any measurement tool that aims to determine the sensitivity of students to cultural heritage. This research is also due to the mentioned requirement. In this context, the aim of the study is to develop a valid and reliable tool that can measure the sensitivity of primary school students to cultural heritage.

The data of the study were collected from primary school 3rd and 4th grade students in the fall term of 2019-2020. Separate sample groups were used for the exploratory and confirmatory factors in the study. In this context, 539 students participated in the exploratory factor analysis study and 327 students in the confirmatory factor analysis study.

A number of analyzes have been used to ensure that the scale developed within the scope of the research is a valid and reliable tool. Expert opinion was consulted to ensure the content validity of the scale. Exploratory Factor Analysis was used for the construct validity of the scale. Cronbach Alpha analysis and correlation mean between 
items were performed for reliability analysis. In addition, item-total score correlations of the items were examined and item discrimination indices were calculated with the t-test analysis. Correlation analysis was used to determine the relationship between the sub-dimensions of the scale and the total score. Confirmatory Factor Analysis was used to test the accuracy of the scale structure resulting from exploratory factor analysis.

In the study, correlation analyzes were carried out between sub-dimensions and between sub-dimensions of the whole scale. The subscales in the cultural heritage sensitivity scale show significant relationships with each other and with the total score. Curiosity subscale was .43 with transferring to the future, .40 with protection; The scale of transposition to the future shows a significant relationship with protection at a value of .40. It was concluded that there was a significant correlation of .88 with the total score of wondering, .76 with the total score of transferring to the future, and .63 with the total score of protection.

Confirmatory factor analysis was used to test whether the 13-item and 3-factor Cultural Heritage Sensitivity Scale, which was developed with exploratory factor analysis, was verified as a model in order to reveal the sensitivity of primary school third and fourth grade students to cultural heritage. Confirmatory factor analysis was carried out with 327 students after the validity and reliability studies of the scale were carried out. The covariance matrix and the maximum likelihood method were used to verify the scale. According to the confirmatory factor analysis, the relationships between factors and observed variables were found to be between .29 and .52 in the curiosity factor; It was observed that the transmission factor ranged from .40 to .57 and in the protection factor between .47 and .67 . In addition, the t-values of the items vary between 4.59 and 10.83 and are significant at the .01 level. When the items are examined, the highest explained variance is .45 and 13 , while the lowest explained variance is .09 and 3. According to the confirmatory factor analysis results of the scale model, fit indexes and modification index results were examined. According to the results of this analysis, $\chi 2=143.86(\mathrm{sd}=62, \mathrm{p}<.001), \chi 2 / \mathrm{sd}$ value $(1.16), \mathrm{RMSEA}=$ $.06, \mathrm{SRMR}=0.056, \mathrm{NFI}=0.89, \mathrm{NNFI}=.92, \mathrm{GFI}=0.93$ and $\mathrm{AGFI}=0.91$. These fit statistics show that the model has a good fit (Kline, 2005; Sümer, 2000; Tabachnick $\&$ Fidell, 2001). Based on these values, it was revealed that the factor structure obtained as a result of the exploratory factor analysis of the sensitivity scale to cultural heritage was confirmed.

Consequently, in this study, it is aimed to develop a valid and reliable measurement tool to measure cultural heritage sensitivity of primary school students. Within the scope of validity and reliability analyzes, a three-dimensional fourdimensional Likert type (1: I do not agree at all, 2: I do not agree, 3: I agree, 4: I absolutely agree) measurement tool was developed. The Scale of Sensitivity to Cultural Heritage consists of "Curiosity", "Transferring to the Future" and "Protection" sub-dimensions. While the highest score that can be obtained from the 
scale is 52 , the lowest score is 13 . In this case, 13-25 points indicate low, 26-38 points medium and 39-52 points indicate a high level of sensitivity to cultural heritage. The higher the score on the scale points out the higher the sensitivity to cultural heritage. As a result of these analyzes, it was found out that the scale was a valid and reliable tool for measuring the cultural heritage sensitivity of primary school students. According to these findings, this scale can be used in other studies. In addition, validity and reliability studies can be done in order to be used at secondary school level. In addition, since this research is limited to scale development research, descriptive and relational studies can be carried out using this scale. 